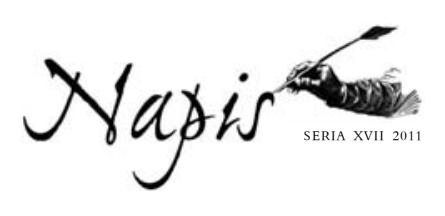

\title{
Anita Frankowiak
}

\section{„Wszystko zaczynało się od mojej obecności”. Sekretny przekaz prozy Andrzeja Stasiuka}

\begin{abstract}
A ndrzej Stasiuk wszedł do literatury trochę „kuchennymi schodami”. Niewielu 1 sądziło, że poza wydanymi w 1992 r. Murami Hebronu napisze coś wartościowego. Sytuacja uległa zmianie, gdy trzy lata później ukazał się Biały kruk i Opowieści galicyjskie, a dwa lata później Dukla. Metafizyczny kontekst jego twórczości wzrastał wraz z każdą kolejną wydaną książką. Determinantą stało się poszukiwanie sensu, bowiem to właśnie „życie pełne sensu stanowi pierwszą, najważniejszą z reguł umiejętnego życia. Kolejną regułą życia umiejętnego, obok nadawania życiu sensu, jest życie chwilą bieżącą"1.

Dziś wiadomo, że Stasiuk należy do grona pisarzy chętnie czytanych i tłumaczonych na wiele języków. Wiadomo też, że historie malowane w krajobrazie zapomnianych zakątków Europy są jednym z ciekawszych wariantów dyskusji o prozie tego pisarza. Wraz z każdą przeczytaną stroną odsłania się coraz wyższy poziom wrażliwości na szczegół i choć zmieniają się krajobrazy, mamy poczucie, że wszystkie opisy łączą się w spójną konstrukcję. A wszystko, jak podkreśla pisarz, zaczęło się od jego obecności². Ta silna, widoczna szczególnie w ostatnich książkach (Moja Europa. Dwa Eseje o Europie Zwanej Środkowa - napisana z Jurijem Andruchowyczem 2000, Zima 2001, Jadac do Babadag 2004, Fado 2006, Dojczland 2007, Taksim 2009 i Dziennik pisany później wydany w 2010 r.), zintegrowana europejska tożsamość, jest wynikiem rekonstrukcji prywatnej narracji. Narracji poszukującej. Narracji wędrowca.
\end{abstract}

T. Gadacz, O umiejętności życia, Kraków 2005, s. 26.

2 A. Stasiuk, Jadac do Babadag, Czarne 2004, s. 10. 
Jeśli jednak popatrzymy na prozę europejską XXI wieku to wędrówka, a właściwie przemierzanie starego kontynentu z filozoficzną i socjologiczną zadumą, nie jest niczym wyjątkowym:

Narracja tożsamościowa w ramach refleksyjnego projektu tożsamości jest z natury rzeczą kruchą. Rezygnacja z konkretnej tożsamości może dostarczyć określonych korzyści psychicznych, ale jest też z pewnością ciężarem. Jednostka jest zmuszona sama tworzyć i przebudowywać swoją tożsamość ze względu na zmienne doświadczenia życia codziennego i skłonność nowoczesnych instytucji do fragmentaryzacji tożsamości jednostki³.

Autor kreśli jednak dość specyficzną narrację tożsamościową. Chce, aby jego świat ocalał. By nie ulegał procesom globalizacji i europeizacji. Dlatego też:

Stasiuk zabiera czytelnika w podróż, będąc absolutnie przewodnikiem, po miejscach, których nigdy nie odwiedziłby z folderową wycieczką, a dwa, iż właśnie wspomina tak jakoś przy okazji o postaciach, które nie zainteresowałyby nikogo poza pasjonatami historyczno-literackimi opisywanych regionów ${ }^{4}$.

Jego stosunek do miejsca - być może tylko lub aż mentalnego, zwanego Europą - jest patrzeniem wyrzutka. Wykorzystując outsiderowską retorykę pisarz próbuje, niestety bezskutecznie, zamknąć tę przestrzeń przed dostępem nowoczesności. Można postawić pytanie czy Stasiuk chce stworzyć alternatywną opowieść? Czy pod jego doświadczeniem powierzchni rzeczy kryje się sekretny przekaz? Idąc tym tropem warto zaznaczyć, że, jak stwierdza Bronisław Bakuła: „obszar wschodnio- i zachodniosłowiański stanowi w sferze literatury zjawisko niejednorodne, a wzajemna relacja dwóch zjawisk okresu transformacji, to jest rekonstruowanego narodowego dyskursu oraz przychodzącego z zewnątrz postmodernizmu, wskazuje na ich stosunkowo słabe przenikanie. [...] Zamiast centrum na plan pierwszy wkracza kategoria pogranicza, peryferii, małej grupy, a nawet subkultury" ${ }^{\text {. }} \mathrm{Z}$ tych znaczeń pisarz korzysta w pełni. Wpisuje się tym samym w ten model opisu, który stosują Jurij Andruchowycz, Ołeksandr Hrycenko czy Oksana Zabużko6.

3 A. Giddens, Nowoczesność i tożsamośc. „Ja” i spoteczeństwo w epoce późnej nowoczesności, tłum. A. Szulżycka, Warszawa 2010, s. 249.

4 J. Lengauer, „Fado” — Andrzej Stasiuk (recenzja), cyt. za: www.libertas.pl (stan z dnia 7 maja 2011 r.).

5 B. Bakuła, Historia i komparatystyka. Szkice o literaturze i kulturze Europy Środkowo-Wschodniej XX wieku, Poznań 2000, s. 176.

6 Por. J. Andruchowycz, A. Stasiuk, Moja Europa. Dwa eseje o Europie zwanej Środkowa, Wołowiec 2000; Sny o Europie, wybór i red. O. Hnatiuk, tłum. O. Hnatiuk, K. Kotyńska, R. Rusnak, Kraków 2005; J. Andruchowycz, Dwanaście kręgów, tłum. K. Kotyńska, Wołowiec 2008. 
Samotne wędrówki sprzyjają odkrywaniu prawd nadrzędnych i pytaniu o sens życia. Stąd można odnieść wrażenie, że Stasiuk wciąż pisze o tym samym. Zmienia tylko bohaterów. To jednak zbyt uproszczona interpretacja. Paradoks rozdarcia między „wiem” a „nie wiem” scala te wszystkie biografie i stąd to mylne przekonanie.

Nie znam dzisiejszych polskich pisarzy, którzy by z równym uporem drążyli skorupę postpeerelowskiej rzeczywistości w poszukiwaniu nie ilustrowanych przygód i nie odpustowych mitów lecz — ni mniej ni więcej - czystego absolutu. Stasiuk wie, że jest to trochę misja Don Kichota i śmieje się (on, samozwańczy „czereśniacki Budda”), lecz idzie tam, gdzie idzie, a po drodze mu przez Duklę właśnie.

Pisarz celebruje samotność i podróż. Pisze: „Podróżować to znaczy żyć. A w każdym razie żyć podwójnie, potrójnie, wielokrotnie" ${ }^{8}$. Żyć by pisać. Manifest literacki Stasiuka brzmi: „Pisać, skreślać, myśleć, patrzeć, słuchać, pisać i skreślać, skreślać, skreślać...”.

\section{Odczytanie I: język rzeczy}

O szczególnym przywiązaniu Andrzeja Stasiuka do opisu rzeczy i miejsc pisałam w kontekście hiszpańskiego personalizmu ${ }^{10}$. Eskapizm, podróż, opisy odległych, nikomu nieznanych zakątków Europy, uchwycenie tego, co przemija najszybciej - materii - to dominanty tematyczne. Są więc w jego utworach małe, brudne przygraniczne miasteczka, bieda, zepsute lampy, kończąca się nagle droga, śmierdzące szamba, zardzewiałe auta, rozpadające się chałupy, opustoszałe bocznice kolejowe, drogi zawieszone na bokach skał, ortalionowe dresy, emaliowane „na niebiesko” garnki, „wielkie tandetne budziki”, puste przestrzenie, walka o przetrwanie, czas zatrzymany w miejscu, tygiel etniczności. Jest też język - barometr kondycji emocjonalnej bohaterów. Istnieje bowiem ścisły związek między „życiem społeczeństwa a słownictwem języka, jakim to społeczeństwo mówi. Odnosi się to w tym samym stopniu do zewnętrznych przejawów życia, jak i do życia wewnętrznego, niedostrzegalnego gołym okiem"11.

Świat przedmiotów jest dla pisarza bardzo ważny. W jednym z wywiadów powiedział:

Coś z tym światem przedmiotów, porównywalnym ze światem przyrody trzeba będzie zrobić. To zbyt ważna część świata, żeby miała tak przepaść.

\footnotetext{
7 P. Siemion, Perspektywy rozwoju matych miasteczek, http://niniwa2.cba.pl (stan z dnia 6 maja 2011 r.).

8 A. Stasiuk, Fado, Wołowiec 2006, s. 39.

9 Cyt. za: www.culture.pl (stan z dnia 10 maja 2011 r.).

10 Por: A. Frankowiak, Proza Andrzeja Stasiuka w perspektywie personalizmu Miguela de Unamuno, w: Między Ztotym a Srebrnym wiekiem kultury hiszpańskiej, pod red. M. Jagłowskiego, D. Sepczyńskiej, A. Frankowiak, Olsztyn 2008, s. 389-396.

11 A. Wierzbicka, Stowa klucze. Różne języki - różne kultury, Warszawa 2007, s. 16.
} 
Może będzie istniało powołane jakimś specjalnym dekretem niebo przedmiotów? Należna im porcja wieczności, zwłaszcza dla tych najbardziej nietrwałych: długopisów i zapalniczek jednorazowych ${ }^{12}$.

W nietrwałości tych przedmiotów, jak w lustrze ogląda Stasiuk poszarpane biografie samotnych, opuszczonych i zapomnianych przez „wielki świat” ludzi z przygranicznych miasteczek i wsi. Z ubolewaniem stwierdza, że:

W naszym świecie jest coraz mniej starych rzeczy i miejsc. Niedługo zatracimy pamięć o tym, skąd się wzięliśmy, i za nic w świecie nie uwierzymy, że nasze ciała, wcale nie tak dawno, wydzielały taką samą woń jak ciała rumuńskich pasterzy ${ }^{13}$.

Cała ta rupieciarnia niechcianych atrybutów istnienia zapełnia Europę Środkową, a jednocześnie stanowi początek tworzenia jej mapy mentalnej. Warto pamiętać, że hybrydyczny, poplątany, niejednorodny i nie zawsze wytłumaczalny charakter Europy Środkowej, tworzy nader specyficzną kulturowo przestrzeń ${ }^{14}$, z którą Stasiuk nie zawsze umie się zmierzyć.

Wikła swych bohaterów w trudną egzystencję, a czytelnika wrzuca do śmietnika szczegółów ${ }^{15}$. Pisze:

Życie przybiera gotowe formy, odbija i załamuje światło i jestem bezradny. Twarze, ramiona, piersi, pośladki — kompletna klęska analizy. Papierosy, stroje, biżuteria, obcasy, koronkowe żaboty, komórkowe telefony przy paskach, breloczki, bida z nędzą [...], domy, mieszkania, Matka Boska, kryształy, lśnienie regałów z Kronika XX wieku, skóropodobne kanapy, paprotki na parapetach, zapach sypialni, krystaliczne wyświetlacze czasu i funkcji, odświeżacze w sraczach, gumoleum, serce Jezusa w rokokowych ramach [...] piec, gumiaki w sieni, ziemniaki w skrzyni [...]. Rzeczy wchodzą między idee i rwą ostrymi krawędziami ich delikatne brzegi i wszystko, co ogólne, w końcu ląduje na śmietniku wśród szczegółów. Caro salutis est cardo ${ }^{16}$.

\footnotetext{
12 Patroszenie świata. Z Andrzejem Stasiukiem rozmawia Katarzyna Janowska i Piotr Mucharski, http://tygodnik.com.pl (stan z dnia 7 maja 2011 r.).

13 A. Stasiuk, Fado, op. cit., s. 65.

14 Dość ciekawie w tym kontekście przedstawia się artykuł Bogusława Zielińskiego zatytułowany Europa Środkowa, czyli Arkadia, Atlantyda i Jeruzalem ( $w$ : Narodowy $i$ ponadnarodowy model kultury. Europa Środkowa i Pótwysep Batkański, pod red. idem, Poznań 2002, s. 39-57). Por. także: A. Applebaum, Między Wschodem a Zachodem. Przez pogranicza Europy, tłum. E. Kulik-Bielińska, Warszawa 2009.

${ }_{15}$ Pisałam o tym w artykule „Pętelka historii i guzik teraźniejszości” czyli o samotności, lęku i środkowoeuropejskim istnieniu w prozie Andrzeja Stasiuka („Studia Ełckie” 2008, nr 10, s. 9-17).

16 A. Stasiuk, Dukla, Czarne 1997, s. 83-84.
} 
Bycie bohaterów w świecie rzeczy jest beznamiętne, spowolnione, wyizolowane, kulturowo niejednorodne. Mietek z Zimy na pytanie co będzie robil, odpowiada, że nic. To „nic” staje się strukturą świata, a „powtarzalność rzeczy i zdarzeń uzyskuje ciągłą strukturę nieruchomości”" ${ }^{\prime 7}$. Zawieszenie, trwanie, „niepotrzebne rzeczy leżące za chałupami w pokrzywach”, „resztki łańcuchów po umarłych ze starości psach” to wszystko „osuwa się”, bo „świat nie kończy się hukiem, ale rdzewieniem” pisze Stasiuk ${ }^{18}$.

Proponuje więc „powrót do rzeczy”, by doświadczyć tego, co pierwotne. By odczuć fenomen istnienia. Stąd też nawet jego wyobrażenie nieba jest nietrwałe, plastikowe, jak jednorazowe łyżeczki i kubki. Są potrzebne współczesnemu człowiekowi, a jeśli niebo jest rajem to muszą tam się znaleźć, by człowiek czuł się komfortowo. W świecie rzeczy starość nikomu nie jest potrzebna — ,jest przestępstwem”.

Konceptualizacja „krajobrazu próchniejącej materii” odbywa się poprzez diagnozę szczegółów, drobnych elementów, splątanych wątków, ułamkowe istnienia, nic nie znaczące z pozoru gesty. Monotonia codzienności zabija egzystencję. Bohaterów odczytujemy wszystkimi zmysłami, czujemy ich obecność, ich oddech na plecach: „Są skonkretyzowani, wyobcowani, wduszeni w stertę niepotrzebnych znaczeń, wokół których rozwija się fabuła i inne bezimienne postaci” ${ }^{19}$. Stasiuk pisze: „Dziesiątki, setki, na całej trasie tysiące ciał i dusz próbowało każde na swój sposób uporać się z dniem”20.

Z tych wszystkich historii i opisów „wydobywa się interesująca koncepcja postrzegania rzeczywistości; swoista obsesja czasu i przestrzeni; powtarzający się motyw pościgu i ucieczki jako dwóch aspektów tej samej „podróży”. Dostrzegalna staje się własna, dość oryginalna estetyka, a także naturalizm, swoje źródła posiadający może w twórczości Hłaski [...]”21. Czas Europy Środkowej jest „gorszą wersją zesłaną tu za karę, czas sekend hend [...]". ${ }^{22}$ Gdyby czas miał inny charakter to kulturowy pluralizm tożsamościowy nie byłby możliwy. Rzeczywistość rzeczy, ta fizykalna strona natury człowieka jest przerażająca. Bohaterowie albo nie mają nic, albo kupują zbyt wiele. Tymczasowość posiadania zabija sens rzeczy. „Jeszcze niedawno kupowali rzeczy na całe życie. Składali, oszczędzali na garnitur u krawca, na buty u szewca i była inwestycja, i był sens, było wyrzeczenie i była nagroda” ${ }^{23}$. A teraz cóż „wszyscy będą mieli wszystko. Chujowe, jednorazowe, fabrycznie przecwelowane, ale bez ograniczeń. Żadnych zasad poza dostępnością, bo wszystko będzie się rozpierdalało coraz

\footnotetext{
17 A. Stasiuk, Zima, Wołowiec 2001, s. 16.

18 Ibidem, s. 25, 26 i 27.

19 M. Orski, Wszystko byto pustym gestem, „Odra” 1995, nr 12, s. 57.

20 A. Stasiuk, Dukla, op. cit., s. 8.

21 M. Nawrocki, No więc „Dukla”. O prozatorskiej twórczości Andrzeja Stasiuka, „Dekada Literacka” 1998, (4) 140; tekst dostępny także na stronie internetowej: www.dekadaliteracka.pl (stan z dnia 10 maja 2011 r.).

22 A. Stasiuk, Zima, op. cit., s. 37.

23 A. Stasiuk, Taksim, Wołowiec 2009, s. 188.
} 
szybciej, w trymiga, zaraz po założeniu, na pierwszym deszczu, natychmiast, jak tylko tego dotkniesz"24. Możliwość wyboru staje się koniecznością. Ryzyko popełnienia błędu zerowe. Rzeczy można zamieniać. Rzeczywistość unicestwić. O przeszłości zapomnieć. Teraźniejszość zaanektowała przyszłość, bo ta jest nietrwała, tandetna i plastikowa. W tytułowym opowiadaniu Zima z cytowanego już w tym omówieniu zbioru Stasiuk pisze: „Tak chciałbym zaczynać wszystkie historie. Od ciał i rzeczy, ponieważ nie starcza mi wiary we wskrzeszenie jednych i drugich" 25 .

Odczytanie pierwsze jest możliwe dzięki językowi rzeczy. To one mają moc kreowania świata. One też mogą nas unicestwić. Zasypać. Przytłoczyć. I choć Francis Fukuyama w Końcu człowieka ${ }^{26}$ wskazuje na inne, potężniejsze rodzaje zagrożeń (neurofarmakologia, sterowanie zachowaniami ludzkimi, inżynieria genetyczna), to sterta niepotrzebnych rzeczy osuwająca się gdzieś w niewiadomą (mentalną) przepaść, jest wyraźną wizją zagłady świata, który np. Jurij Andruchowycz próbuje ocalić przez reinterpretację ruin domów, mostów, dróg i cmentarzy. Obraz prywatnej Europy jest budowany na strzępach znaczeń, które emocjonalnie są trwalsze niż materia, mimo że ta właśnie świadczy o rozwoju naszej cywilizacji.

\section{Odczytanie II: język samotności}

Pisarz stawia pytania egzystencjalne, które odnoszą się do podstawowych zagrożeń i lęków, jakich doznaje człowiek pogranicza. To zasadniczy kontrapunkt dla „języka rzeczy”. Już w tomie opowiadań Przez rzekę i w Opowieściach galicyjskich bohaterowie są zanurzeni w nie-istnieniu i nie-trwaniu. „Nicość nie «jest», nie trwa i nie ma w sobie możności, a przez to nie dzieje się"27. Kostek-przybłęda w Białym kruku, Józek-traktorzysta, Janek i Maryśka z Opowieści galicyjskich, Wasyl-alkoholik i Zula Egipt-anioł i halucynacja zarazem ze zbioru Przez rzekę, Pawel-rencista i Mietek-drwal i kłusownik, który nie może istnieć bez Żłobisk, Koprywiczej, Wyżnej Woli z Zimy, Władek i Paweł z Taksimu — to ludzie pozbawieni perspektyw, ale bardzo mocno związani z miejscem. Nad większością bohaterów rozpościera się aura klęski. Tożsamość jednostki rozpada się na bycie i trwanie. W traumatycznych, bądź po prostu trudnych doświadczeniach, tożsamość jednostki staje się „przedsięwzięciem refleksyjnym”. Jak stwierdza Anthony Giddens:

Refleksyjny projekt „ja”, który polega na utrzymywaniu spójnych, chociaż wciąż na bieżąco weryfikowanych narracji biograficznych, rozgrywa

24 Ibidem, s. 189.

25 A. Stasiuk, Zima, Wołowiec 2001, s. 40.

${ }^{26}$ F. Fukuyama, Koniec człowieka. Konsekwencje rewolucji biotechnologicznej, tłum. B. Pietrzyk, Kraków 2008.

27 L. Ostasz, Potencjalność-byt-chaos-nicość. Rozważania metafizyczne, Kraków 1998, s. 70. 
się w kontekście wielokrotnego wyboru zapośredniczonego przez systemy abstrakcyjne. Pojęcie stylu życia nabiera w warunkach nowoczesności szczególnego znaczenia. Wraz ze słabnącym oddziaływaniem tradycji i rosnącym udziałem dialektycznego współoddziaływania globalności i lokalności w rekonstytuowaniu życia codziennego, jednostki są zmuszone budować swoją tożsamość, wybierając pośród różnorakich opcji ${ }^{28}$.

Bohaterowie Stasiuka egzystują. Jeśli działają to przez wykluczenie, alienację lub marginalizację. Ich działania ograniczają się do prymitywnego konsumpcjonizmu, a wszelkie próby zmiany przyjmowane są z oporem i bardzo niechętnie. Wielkie miasta i lepsze miejsca gdzieś są, ale nawet ci, którzy chcą wybiec ze swoich przestrzeni i postrzegają je jako krainę Kanaan, rezygnują w ostatnim momencie, uciekają z przystanku PKS i powracają do monotonnych zajęć.

Magicznym miejscem obserwacji prywatnej Europy jest dla Andrzeja Stasiuka Dukla — swoista „Ultima Thule” — jak pisze. Kilka ulic na krzyż, punkt na mapie. Doskonałość skończoności. Jest „punktem odniesienia, może nawet jedynym stałym punktem we wszechświecie. Wypadkową tego, co było i tego, co jest. Miejscem, w którym zaczyna się czas i przestrzeń. Czasoprzestrzenią mityczną (a może zmitologizowaną). [...] Odskocznią do podróży w przeszłość. Intelektualnym i emocjonalnym katalizatorem. A może rzeczywiście - metafizycznym „szybem wentylacyjno-wydobywczym"? ${ }^{29}$. Z tego miejsca rozchodzą i zwielokrotniają się drogi pisarskich eskapad. Są opuszczone Karpaty, zapomniane Żłobiska, przedmieścia miast „ze swoimi psimi budami i rupieciarnią"30. Są drogi prowadzące donikąd. Jasne jest więc, że metaforycznie rozpadająca się materia i rozłażący czas to kod dostępu do zdeterminowanego prymitywnymi pojęciami światopoglądu tych wszystkich sportretowanych: Józków, Władków, Mietków, Grześków i Heńków.

W takim kontekście „Dukla Stasiuka jest dialogiem, spowiedzią, wyjściem ku drugiemu człowiekowi, lawkową komunią we wspólnym zdejmowaniu opornego kapsla z piwnej flaszki Istnienia”31. Na naszych oczach powstaje niezwykła mapa. Stasiuk buduje mapę ocalenia i rozpadu jednocześnie. Jest w Fado krótkie wspomnienie z wizyty Jana Pawła II, w którym Stasiuk daje wykładnię cierpienia, heroizmu, odwagi i mądrości ludzkiej. Czytamy: „Wyglądał krucho i samotnie. [...] Nigdy w życiu nie widziałem kogoś tak samotnego." ${ }^{2}$. Jednak to nie samotność interesuje pisarza najbardziej. To byłoby zbyt banalne. Szuka kolejnego punktu na swojej emocjonalnej mapie. Staje się nim człowieczeń-

28 A. Giddens, op. cit., s. 16-17.

29 M. Nawrocki, No więc „Dukla”..., op. cit.

30 A. Stasiuk, Taksim, Wołowiec 2009, s. 53.

31 P. Siemion, Perspektywy rozwoju matych miasteczek, op. cit.

32 A. Stasiuk, Fado, op. cit., s. 147 i 148. 
stwo. Papież-człowiek, Papież-chory i stary. Papież Polak i Europejczyk. W oczekiwaniu na śmierć i jednocześnie dający nadzieję milionom pielgrzymów. Sekret tkwi w odwadze umierania. „On miał odwagę umierać na oczach milionów, miał odwagę stawiać nam przed oczy swoje wynędzniałe ciało, swoją twarz ściągniętą cierpieniem, swoje powłóczenie nogami, swoją agonię. To była jego ostatnia lekcja, gdy nie mógł już mówić”’33.

Stasiuk udowadnia, jak trudno zbudować zaufanie, otworzyć się na innych, zrozumieć starość, śmierć i cierpienie. Zmaga się z cielesnością bytu, z „jestestwem” i „byciem”. W szczególny sposób „rozprawia się” z sekretem istnienia w „nieokreślonej sumie skończoności”.

Odczytanie drugie ma sens jeśli popatrzymy na prozę Stasiuka poprzez pryzmat młodej literatury europejskiej ${ }^{34}$. Język alienacji, trauma opuszczenia, kategoria obcości to dylematy i tematy wyznaczające jedną z bardziej krętych i zagadkowych dróg, którymi podąża proza XXI wieku.

\section{Odczytanie III: sekret}

Stasiuk wciąga czytelników do swojego świata.

Czyni to rezygnując niemal z jakiejkolwiek akcji i zaludniając książkę bohaterami podobnymi do siebie. Są głupsi, mądrzejsi, podli lub choć trochę szlachetni, niemniej wycięci z tego samego formatu. A jednak działa. Dziwne to, bo gdyby ich spotkać, nie znaleźlibyśmy wspólnego języka ${ }^{35}$.

A jednak są nam bliscy. W czym więc tkwi sekret prozy Stasiuka? Nie chodzi przecież tylko o pierwszoosobową narrację, bo byłoby to banalne. Wrażliwość pisarza także nie jest odpowiedzią pełną choć przekonuje, że najtrudniej poznać świat wewnętrzny. Bohaterowie dziwią się więc swoim reakcjom, są zaskoczeni uczuciami. Żyją w kulturze zdominowanej przez plastik, podróbki i obrazki, trwają zanurzeni w kulturze homogenizowanej, a więc „gotowej do spożycia”. Diagnoza jest przerażająca. Nie ma tabu, nie ma sacrum, autorytety umarły. Zrzuciliśmy z piedestału wartości, a niebo jest puste. Pisarz twierdzi, że „być może trzeba się skupić na opisywaniu strzępów, fragmentów, żeby nie oszaleć, żeby nie zwariować. Żeby nie stwierdzić, że ludzki umysł się skończył”36.

\footnotetext{
33 Ibidem, s. 151.

34 Wystarczy wspomnieć: Ch. Tsiolkas, Martwa Europa, tłum. M. Płaza, Warszawa 2010; K. Varga, Gulasz z turula, Wołowiec 2008; J. Sosnowski, Ach, Kraków 2005; S. Żadan, Big Mac, tłum. M. Petryk, Wołowiec 2005; Ograbiony naród. Rozmowy z intelektualistami białoruskimi - Małgorzata Nocuń, Andrzej Brzeziecki, Warszawa 2008.

35 Cyt. za: http://kafeteria.pl/kultura (stan z dnia 2 maja 2011 r.).

36 Patroszenie świata. Z Andrzejem Stasiukiem rozmawiaja Katarzyna Janowska i Piotr Mucharski, http:// tygodnik.com.pl (stan z dnia 7 maja 2011 r.).
} 
Czyżby wizja Europy w XXI wieku była rzeczywiście Baumanowskim „dyskursem bez granic”? Z perspektywy czasu wydaje się, że pojęcia takie jak: Europa Zachodnia, Europa Wschodnia, Europa Środkowa nie wystarczają współczesnej humanistyce. Wspótczesna Europa $w$ procesie zmian (by przywołać tytuł zbioru szkiców z 2006 r. ${ }^{37}$ ) też nie ułatwia odczytania. Kodem dostępu nie jest też Europa bez granic. Pozostaje jeszcze jeden ważny element odczytania, prywatna Europa, a właściwie prywatne Europy. „Europejska jedność to tylko gadanina. Na wschodzie schizma, na Południu herezja. Tylko na Zachodzie europejska ortodoksja"38 — pisze Stasiuk. Jakie jest więc trzecie odczytanie? Pisarz z miną kpiarza powiedziałby pewnie: Europa w wersji „hard”, „Europa great”, „Europa beautiful”. Trwanie zakotwiczone w śmierci. Kolorowy labirynt znaczeń i życie z dykty i kartonu. „Egzotyka masowych grobów”, resztki materii. „Wszystko niby twoje, ale jakieś takie znalezione. Niemieckie, żydowskie, ukraińskie, panieńskie, miejskie. Teraz jest wszechświatowe i chińskie"39. Czyżby Europa poszukiwana? To zbyt oczywiste.

„Stasiuk bardzo pięknie mówi o wielokulturowości, wieloetniczności Europy. Namawia wręcz do dostrzegania tych części naszego kontynentu, które może niebawem znikną, które pochłonie tzw. cywilizacja"40. Powiedzieć, że przyszłość jest dla Stasiuka kulturową i ontologiczną pustynią, to tak, jakby zapomnieć, że właśnie wyobrażenie przyszłej Europy buduje pisarz na naszych oczach:

Ma zniknąć to wszystko, z czego składały się te strony. Ma zniknąć bałagan, nieporządek, nieodpowiedzialność, niefrasobliwość, ma wyzionąć ducha perwersyjna miłość do przeklętej historii, ma zakończyć żywot skłonność do konfabulacji, pociąg do zmyślenia też ma umrzeć, a umiłowanie do fikcji zastąpi wiara w raz daną rzeczywistość. Jednym słowem, ma zginąć świat, który cierpliwie budowaliśmy ${ }^{41}$.

Trzeba więc ratować tę zaściankową rupieciarnię. Jednak podróżowanie do miejsc zapomnianych i opisywanie ginącego świata nie jest sekretem tej prozy.

Tajemnicą jest ucieczka od bylejakości i wytworzenie dystansu do polskości. Trochę w tym Gombrowicza, a trochę Słowackiego. Zabrzmi to przewrotnie, ale Stasiuk uczy się polskości. Odrzuca tę oficjalną gazetową, polityczną i wielkomiejską. Chce odczuć polskość ułomną i chimeryczną. Patrzy na nią z Albanii, Słowacji, Rumunii, Serbii

\footnotetext{
${ }^{37}$ Wspótczesna Europa $w$ procesie zmian. Wybrane problemy, pod red. J. Polakowskiej-Kujawy, Warszawa 2006.

38 A. Stasiuk, Dziennik pisany później, Wołowiec 2010, s. 121.

39 Ibidem, s. 141.

40 J. Lengauer, „Fado” — Andrzej Stasiuk (recenzja), op. cit.

41 A. Stasiuk, Fado, op. cit., s. 73.
} 
i Bośni. W wywiadzie zamieszczonym 25 listopada 2010 r. w „Dużym Formacie”, dodatku do „Gazety Wyborczej” powiedział: „Otwartym tekstem wreszcie pojechałem. Chciałem sobie poużywać słowa Polska. Mogłem sobie pozwolić, bo prawie nigdy w żadnej mojej książce tego nie robiłem” ${ }^{42}$. Jak stwierdza jeden recenzentów: „Najbardziej ciekawie robi się zresztą w Dzienniku pisanym później właśnie wówczas, gdy przechodzi od bałkańskości do polskości, gdy uświadamia sobie, że nie ma ucieczki przed własną pamięcią — indywidualną i zbiorową. Że Polska boli najbardziej, ale też najbardziej pociąga. Stasiuk, powtarzający w ostatniej części książki jak mantrę sformułowanie: „Mój kraj”, wydaje się wkraczać na całkiem nowe terytoria, odkrywać świadomość przynależności do pewnej społeczności połączonej historią i tradycją" ${ }^{43}$. Polska rozpięta między Wschodem a Zachodem, pomiędzy trwaniem a przemijaniem jest leniwa i apatyczna. Ale jest to także kraina wyrzutków Zachodu i zdrajców Wschodu: „Samotni i niewinni. W smrodzie niezagojonych ran, w roju much, w szmatach, złotogłowiach, atłasach, obwieszeni brzękadłami, poprzebierani za innych, bez Mojżesza [...]"44.

Pisarz niewątpliwie tworzy alternatywną opowieść. Nie pisze o łacińskim Zachodzie, greckim Wschodzie i wyalienowanym, rozdartym Środku. Pisze o rupieciarni mentalnej. Jak jednak podkreśliła kilka lat temu Maria Janion: „dzisiejsza rekonstrukcja pojęcia Europy Środkowo-Wschodniej wymaga zdystansowania się od przyjętego i dyskutowanego przed dwudziestu laty mitu kulturowego i politycznego" ${ }^{45}$. Stasiuk to robi. Kreśli prywatną religię, prywatną Europę, prywatną Polskę:

Nasza. Stepowa. Oddzielna. Wolni od przeklętych porównań z innymi szlibyśmy samotni i beztroscy pod ochroną Dziewczęcia, pod jej bezkresną niebieską suknią. Tylko my i Ona na całym świecie. Ta. Ona i my. $\mathrm{Na}$ wieki. Polska ${ }^{46}$.

Trzecią część Dziennika... rozpoczyna motto filozofa Emila Ciorana, który przez całe swoje życie oswajał się z rumuńskością. Podobnie jest ze Stasiukiem. To oswajanie polskości jest procesem ciągłym i obojętnie jak nazwiemy jego książki - czy będą to „powieści drogi”, westerny, bądź dzienniki podróży, to każdy opis Stasiuka można interpretować w kontekście słów Witolda Gombrowicza ${ }^{47}$ :

${ }^{42}$ Mam romanse z geografia. Z Andrzejem Stasiukiem rozmawia Dorota Wodecka, http://wyborcza.pl (stan z dnia 5 czerwca 2011 r.).

43 A. Stasiuk, Dziennik pisany później (recenzja anonimowa), www.zyciewarszawy.pl (stan z dnia 12 maja 2011 r.).

44 A. Stasiuk, Dziennik pisany później, op. cit., s. 160.

45 M. Janion, Niesamowita Stowiańszczyzna. Fantazmaty literatury, Kraków 2006, s. 21.

46 A. Stasiuk, Dziennik pisany później, op. cit., s. 161.

47 Stanisław Stabro napisał, że: „Gombrowicz wchodząc w ironiczny spór z Polską i z jej mocarstwowymi ambicjami, charakteryzował ją jako przejściowy kraj formy osłabionej, pomiędzy Wschodem 
Śmietnik. W tym sęk, że ja wywodzę się z waszego śmietnika. We mnie odzywa się to, co wy w ciągu wieków wyrzucaliście jako odpadki. Jeśli moja forma jest parodią formy, to mój duch jest parodią ducha, a moja osoba parodią osoby ${ }^{48}$.

W Fado ${ }^{49}$ Stasiuk proponuje parodię jako jedyny sposób przetrwania starej Europy. Być może sekretnym przesłaniem jego prozy jest więc prywatna Europa zanurzona w egzystencjalnym i mentalnym śmietniku.

\section{Anita Frankowiak, „It all began with my presence.” Secret message of prose of Andrzej Stasiuk}

The first novel by Stasiuk not yet announcing the birth of the sensitive, immune to schemes, still outspoken writer in Europe. Starting from Dukla philosophical context for work of Stasiuk increases with every published book. In his vision the Central European existence has been stigmatized by history, marked by loss, limited mentally, ragged with anxiety, ambiguous and stretched between the mystery and the surface of matter. Domestication of alienation associates with the crossing of borders, especially the ethnic borders. The author believes that we lived and apparently we still live as fictitious entities. Being at home means staying in an idealized past. He concludes, "we can never accept ourselves as we are". Lack of acceptance creates frustration and anxiety. Loneliness, alienation, anxiety is the fundamental attributes of the ontology Andrzej Stasiuk. A writer struggling with the physicality of existence, the concepts of "selfhood" and "being", trying in his "personal heresy" to solve the secret of existence.

a Zachodem”. Cyt. za: S. Stabro, Witold Gombrowicz — nieprzyswojona lekcja [fragment], http://odra. okis.pl (stan z dnia 5 maja 2011 r.). Podobnie sytuuje Polskę Stasiuk — trwa gdzieś zawieszona między wschodnim nieładem, a zachodnim dobrobytem.

48 W. Gombrowicz, Dziennik 1953-1956, Kraków 1986, s. 60.

49 Ibidem, s. 68-70. 